\title{
Humic acid interaction with clay minerals. Modification of the surface properties by calcium presence
}

\section{Alejandra M. Fernández Solarte and Mariela A. Fernández}

CETMIC (Centro de Tecnología de Recursos Minerales y Cerámica) CCT-La Plata, CIC. Camino Centenario y 506 (CC.49) (B1897ZCA), M. B. Gonnet, Argentina Fax: +54-221-471-0075

Email: alfito08@hotmail.com

Email:mfernandez@cetmic.unlp.edu.ar

\section{Maria dos Santos Afonso}

Facultad de Ciencias Exactas y Naturales, INQUIMAE and Departamento de Química Inorgánica, Analítica y Química Física, Universidad de Buenos Aires, Ciudad Universitaria Pabellón II 3er Piso, C1428EHA Buenos Aires, Argentina Email: dosantos@qi.fcen.uba.ar

\section{Rosa M. Torres Sánchez*}

CETMIC (Centro de Tecnología de Recursos Minerales y Cerámica) CCT-La Plata, CIC. Camino Centenario y 506 (CC.49) (B1897ZCA),

M. B. Gonnet, Argentina

Fax: +54-221-471-0075

Email: rosats@cetmic.unlp.edu.ar

Email: rosa.torres@gmail.com

${ }^{*}$ Corresponding author

\begin{abstract}
The environmental importance of humic acid (HA) is mainly related to soil fertility, but it can also develop some human diseases by its intake as well as prevent calcium assimilation. Physicochemical characterisations of a montmorillonite (Mt) and its thermal treated product (Mt550), to which HA, $\mathrm{Ca}^{+2}$ or both were added, will help to better understand the surface behaviour of the binary or ternary systems. Calcium or HA adsorption produces a decrease of the Mt and Mt550 specific surface area (SSA). X-ray diffraction indicates calcium presence and no entrance of humic acid in the interlayer of $\mathrm{Mt}$, while in the ternary systems (calcium-HA-Mt) a hindrance to the calcium entrance was observed. The opposite behaviour produces the adsorption of HA or
\end{abstract}


calcium on electric charge of both samples. The mean pore diameter (MPD) for Mt increases with $\mathrm{Ca}^{+2}$ adsorption while no change was found after HA adsorption, in contrast to that found for Mt550.

Keywords: montmorillonite; thermal treated montmorillonite; porosity; specific surface area; humic acid.

Reference to this paper should be made as follows: Fernández Solarte, A.M., Fernández, M.A., dos Santos Afonso, M. and Torres Sánchez, R.M. (2015) 'Humic acid interaction with clay minerals. Modification of the surface properties by calcium presence', Int. J. Environment and Health, Vol. 7, No. 3, pp.215-230.

Biographical notes: Alejandra M. Fernández Solarte has a $\mathrm{PhD}$ in Physics (Rosario National University). Her research interest is related to the development of new technologies translating the bactericide and disinfectant properties to clays and nanoclays. Soil and water pollution were also studied, and generation of ceramics with piezoelectric properties of lead-free compositions by the sol-gel method. She has published seven papers in international peer reviewed journals, two technical reports as well as more than 10 congress presentations.

Mariela A. Fernández has a $\mathrm{PhD}$ in Biotechnology (Quilmes National University). Her research interest is related to the development of new technologies for water remediation including adsorption of heavy metals and agrochemicals. The related adsorbents studied were raw, thermal and mechanical treated and nano-clays. She has published four papers in international peer reviewed journals as well as two book chapters and more than 20 congress presentations.

Maria dos Santos Afonso, PhD in Chemistry, is a Professor at Buenos Aires University where she teaches aquatic chemistry and general chemistry courses. Her research interests focus on biogeochemistry of soils, sediments and aquatic ecosystems, the cycles of water, carbon, nutrients and metals, water-rock interactions, chemistry of organic pollutants such as pesticides and environmental modelling. She has published more than 60 papers in international peer reviewed journals, one book and several book chapters.

Rosa Maria Torres Sánchez, PhD in Natural Sciences, is Principal Researcher in the National Research Council (CONICET). Her research interests focus on clays and soils characterisation, clays application in water and effluent treatments and as agrochemical adsorbents. She teaches several postgraduate courses, published more than 80 papers in international peer reviewed journals, more than 20 book chapters, acted as Editor of four scientific books, and directed several research projects and five PhDs.

\section{Introduction}

Humic acid (HA) is the major component of humic substances (HS) which are the most important organic constituents of soil (humus), peat, coal, many upland streams, dystrophic lakes and ocean water (Stevenson, 1982). HA is produced by biodegradation of dead organic matter during subsurface humidification (Kar et al., 2011). 
Some recent works reveal that HA can act as xenobiotic chemicals (Bittner et al., 2006). Prolonged exposure to water containing HA damages tissues and endothelial cells (Ting et al., 2010; Hseu et al., 2008) with subsequent chronic health problems (Hur et al., 2011; Kihara et al., 2014). Also, high concentration of HA present in artesian well water was suggested as one of the contributing factors for the development of blackfoot disease (BFD) (Hseu et al., 2008) or Kashin-Beck disease (KBD) (Liang et al., 1999). BFD is an endemic peripheral vascular disease found on the southwest coast of Taiwan while KBD is a chronic, endemic osteochondropathy (disease of the bone).

Pharmacological properties of HA, anti-inflammatory, anti-neoplastic and antiproliferative effects (Yang et al., 2004), in the presence of $\mathrm{As}_{2} \mathrm{O}_{3}$, generate growthinhibition effects in human cervical adenocarcinoma cell lines in vitro.

HA are polyelectrolyte acids containing various types of carboxylic and phenolic functional groups as aliphatic and aromatic moieties. The first type of functional groups confers hydrophilic properties, while the latter imparts hydrophobic properties to these substances.

HA tend to accumulate at the solid-water interface due to these hydrophilic and hydrophobic properties. The different chemical functional groups present in the molecule participate in chemical reactions of adsorption and complexation of a variety of metals, metallic oxides, salts, clay minerals and some other non-metallic elements. In this sense, HA can act as a complexing agent on the human body, preventing calcium assimilation.

The presence in water and soil of heavy metals generates an important concern about the environment and health, which has led to the development of large number of investigations to remove these pollutant agents. The HA capacity of heavy metals complexation had been largely studied in order to understand their environmental behaviour in surface waters and soils (Park et al, 2012 and references therein).

It was pointed out that the association of HA with water colloids or clay particles revealed important increase of adsorption of heavy metals, in respect of any of them alone (Wang et al., 2012 and references therein). Also, in anaerobic environments, HA are utilised as electron acceptors or electron shuttles by a variety of bacteria (Vacca et al., 2005; Kappler et al., 2004). With aerobes, exposure to humic materials has been shown to have various effects on metabolic activity in general and on the biodegradation of organic pollutant compounds in particular.

The adsorption of HA by clays has been largely studied, particularly, in binary systems consisting of montmorillonite (Mt) and $\mathrm{HA}$, where an increase in the adsorption capacity of heavy metals was observed, assigned to the bridge bonds generated between divalent metal ions and the surface formed by the system (Liu and Gonzalez, 1999). Recently an increase of around $15 \%$ of the maximum adsorption capacity of $\mathrm{Cr}, \mathrm{Cu}$ and $\mathrm{Cd}$ was also indicated, by the use of ternary systems composed of $\mathrm{Ca}-\mathrm{Mt}$ and $\mathrm{HA}$ (Wu et al., 2011).

The associations between HA and clays were also studied in soil chemistry in order to determine their contribution to soil fertility by affecting aggregation, dispersivity and expandability by modifying the surface area, cationic exchange capacity (CEC) and charge density (Tiller and Smith, 1990). Particularly, the interaction and aggregation of clays with soil organic matter are affected by soil $\mathrm{pH}, \mathrm{CEC}$ and presence of cations $\left(\mathrm{Na}^{+}, \mathrm{Ca}^{2+}, \mathrm{Mg}^{2+}\right)$, which also modifies the transport and bioavailability of nutrients and pollutants (Young and Smith, 2000; An et al., 2015). The amount and type of clays present in soils (Amezkieta, 1999) can act together to form intra-particle interactions influencing soil dispersivity (Nelson et al., 1999). The high specific surface area (SSA) 
and the chemical reactivity developed by clays modify soil properties when the soil's clay content is higher than $30-35 \%$.

The study of the addition of $\mathrm{Ca}^{+2}$ and HA to Mt could represent what occurs in soils and also in the uptake of $\mathrm{Ca}^{+2}$ in human bodies. The reproduction of some of the most important components with heavy metals adsorption capacity in soil and their characterisation could allow predicting the fate of contaminants in different environmental compartments with the effect of physicochemical changes in the environment.

The importance of interactions of clays and HA had been widely studied, in order to understand the aggregation and sedimentation properties of clays in surface waters and particle transport phenomena, (Majzik and Tombácz, 2007a, and references therein). Six mechanisms have been suggested to be involved in the adsorption of organic matter to mineral surfaces: ligand exchange, cation bridges, anion exchange, cation exchange, van der Waals interactions and hydrophobic effects (Arnarson and Keil, 2000).

The layers of clay particles have permanent negative charges on basal planes and pH-dependent charges develop on the surface hydroxyls at the edges. This surface charge heterogeneity of Mt governs the particle interactions in suspension. Although the overall particle charge is always negative, the edges are positively charged under acidic conditions and edge-to-face aggregates can form at and below $\mathrm{pH} \sim 6.5$ (Majzik and Tombácz, 2007a, 2007b). Also, specific mesopore surface area is relevant for adsorption of organic ligands onto $\mathrm{Mt}$, in fact, this mesopore area is increased by calcinations, promoted by the exposure of the aluminium ions at the surface edges (Bojemueller et al., 2001).

The aim of this work is to determine the influence of the presence of $\mathrm{Ca}^{+2}$ and HA on some surface properties of swelling clays. To attain this objective, Mt and thermal treated Mt samples were employed, to which $\mathrm{HA}, \mathrm{Ca}^{+2}$ or both were added to modify their surface characteristics. Particle effective diameter, specific surface (by water adsorption), interlayer space, zeta potential curves and porosity (by Hg intrusion) were measured to determine changes in Mt aggregation and surface electric charge behaviour. Thermal treated Mt was used to point out the influence of clay's internal surface in the parameters studied.

\section{Materials and methods}

\subsection{Materials}

The fraction $<2 \mu \mathrm{m}$ of Mt ( $99 \%$ purity) was isolated by dispersion in water and further centrifugation at 14,000 rpm, from a bentonite sample collected from Lago Pellegrini deposit (Rio Negro, North Patagonia; Argentine).

A fraction of Mt was treated thermally at $550^{\circ} \mathrm{C}$ for $12 \mathrm{~h}$ and identified as Mt550.

Humic acid AR (Na humate 99\% purity) and $\mathrm{CaCO}_{3}$ were supplied by Aldrich. The humic acid (HA) was purified following the Vermeer et al. method (1998) and identified as HA. The HA molar absorption coefficient ratio (measured at $\lambda=465$ and $665 \mathrm{~nm}$ ) was 3.57 indicating $\mathrm{AH}$ characteristics (Stevenson, 1982). The analysis of HA obtained by XRD (figure not shown) evidenced the absence of crystalline inorganic compounds as quartz, clays and calcite. Also, IR characteristics bands 
(figure not shown) for the HA sample were found at $3370-69 \mathrm{~cm}^{-1}$ corresponding to $\mathrm{OH}$ groups stretching of the various carbonyl groups and at $1719-18$ and $1225-23 \mathrm{~cm}^{-1}$ to carboxyl, at 2929 and $2850 \mathrm{~cm}^{-1}$ corresponding to the aliphatic $\mathrm{CH}$ stretch, at $1624-1619 \mathrm{~cm}^{-1}$ assigned to structural vibrations of aromatic groups $\mathrm{C}=\mathrm{C}$ and at $1404-1419 \mathrm{~cm}^{-1}$ belonging to phenols (Barancikova et al., 1997). Both analysis indicated a good purification of the HA.

\subsection{Adsorptiosn of $\mathrm{Ca}^{+2}$ and humic acid.}

For Mt or Mt550 dispersions $(20 \% \mathrm{w} / \mathrm{v}), \mathrm{CaCO}_{3} 0.09 \mathrm{~g} / \mathrm{g}$ clay, HA $0.06 \mathrm{~g} / \mathrm{g}$ clay or both were added and maintained in continuous stirring for $48 \mathrm{~h}$ at room temperature. The amount of $\mathrm{CaCO}_{3}$ added corresponds to three times the $65-70 \%$ CEC. The dispersions were centrifuged $(14,000 \mathrm{rpm})$ and solids were identified with a sub-index indicating the presence of $\mathrm{Ca}^{2+}$, humic acid (HA) or both adsorbates $\left(\mathrm{Mt}_{\mathrm{Ca}}, \mathrm{Mt}_{\mathrm{HA}}\right.$ and $\mathrm{Mt}_{\mathrm{CaHA}}$, respectively).

The HA and $\mathrm{Ca}^{2+}$ adsorption amounts were determined as the difference between initial concentration and that of the supernatant in equilibrium. HA in the supernatant solution (equilibrium concentration) was analysed by UV spectrophotometry (maximum absorption $\lambda=465 \mathrm{~nm}$ ) using a Hewlett-Packard 8453 UV-visible spectrophotometer. The $\mathrm{Ca}^{2+}$ equilibrium concentrations were determined using a Shimadzu 6800 atomic absorption spectrophotometer.

\subsection{Characterisation methods}

$\mathrm{X}$-ray diffraction analyses were carried out on powder samples to determine the basal spaces with a Philips 3710 diffractometer using $\mathrm{Cu} \mathrm{K}_{\alpha}$ radiation $40 \mathrm{kV}, 20 \mathrm{~mA}$ and $\mathrm{Ni}$ filter, samples were stored $12 \mathrm{~h}$ at 0.47 relative humidity (rh) before $\mathrm{X}$-ray analysis.

The external SSA was determined by nitrogen adsorption $\left(\mathrm{S}_{\mathrm{N} 2}\right)$ (BET method, at $\left.-196^{\circ} \mathrm{C}\right)$ using a Quanta Chrome Autosorb instrument and the total SSA $\left(\mathrm{S}_{\mathrm{w}}\right)$ was determined by water vapour adsorption at rh 0.56 , as described elsewhere (Torres Sánchez and Falasca, 1997). Internal or interlayer SSA was determined as the difference of total (Sw) and external $\left(\mathrm{S}_{\mathrm{N}_{2}}\right)$ SSA (Michot and Villieras, 2006).

The values of isoelectric point (IEP) were obtained by determination of the diffusion potential as described elsewhere (Tschapek et al., 1989). The IEP is the $\mathrm{pH}$ when the transported number of cations $\left(t^{+}\right)$is 0.5 in graph $t^{+}$vs. the sample $\mathrm{pH}$. The transport number is obtained from the electromotive force, originated by the electrolyte ions moving within the charged sample between two different concentrations $\left(5 \times 10^{-3}\right.$ and $\left.10^{-3} \mathrm{M}\right)$ of $\mathrm{KCl}$.

The CEC was determined by the $\mathrm{Cu}$-triethylenetetramine method (Czímerová et al., 2006).

Particle size determination was performed by dynamic light scattering DLS measurements using a Brookhaven 90 Plus/Bi-MAS Multi Angle Particle Sizing, operating at $\lambda=635 \mathrm{~nm}, 25 \pm 0.1^{\circ} \mathrm{C}$. Soil particles were measured from $1 \% \mathrm{w} / \mathrm{w}$ water dispersion. The determination only gives an apparent equivalent sphere diameter (Dapp). 
Zeta potential (ZP) measurements were carried out with a Zeta Potential Analyser 90Plus/Bi-MAS Multi Angle Particle Sizing (Brookhaven Instruments Corporation) at constant ionic strength of $10^{-3} \mathrm{M} \mathrm{KCl}$. Samples were prepared at several $\mathrm{pH}$ values and $\mathrm{pH}$ was equilibrated over night by addition of concentrated $\mathrm{HCl}$ or $\mathrm{KOH}$ solutions dropwise.

Textural analyses were carried out using a Porosimeter 2000 Carlo Erba. This instrument determines the pore size and pore volume distribution in the range 3.7-7500 nm radius by $\mathrm{Hg}$ intrusion. The weighed sample was outgassed and then filled with $\mathrm{Hg}$. Pore volume was measured by a capacitance system and with an external pressure range $0.1-200 \mathrm{MPa}$.

\section{Results and discussion}

Table 1 indicates the chemical analysis, external SSA $\left(\mathrm{SN}_{2}\right)$, IEP and CEC of Mt and Mt550 samples.

Table 1 Chemical analysis and external SSA $\left(\mathrm{S}_{\mathrm{N} 2}\right)$, IEP and CEC of indicated samples

\begin{tabular}{|c|c|c|c|c|c|c|c|c|c|c|c|c|c|}
\hline Sample & $\begin{array}{c}\mathrm{SiO}_{2} \\
\%\end{array}$ & $\begin{array}{c}\mathrm{Al}_{2} \mathrm{O}_{3} \\
\%\end{array}$ & $\begin{array}{c}\mathrm{Fe}_{2} \mathrm{O}_{3} \\
\%\end{array}$ & $\begin{array}{c}\mathrm{CaO} \\
\%\end{array}$ & $\begin{array}{c}\mathrm{TiO}_{2} \\
\%\end{array}$ & $\underset{\%}{\mathrm{MgO}}$ & $\begin{array}{c}\mathrm{BaO} \\
\%\end{array}$ & $\begin{array}{c}\mathrm{Na}_{2} \mathrm{O} \\
\%\end{array}$ & $\begin{array}{c}\mathrm{K}_{2} \mathrm{O} \\
\%\end{array}$ & $\begin{array}{l}\mathrm{H}_{2} \mathrm{O} \\
\text { loss }\end{array}$ & $\begin{array}{c}S_{N 2} \\
\left(\mathrm{~m}^{2} / \mathrm{g}\right)\end{array}$ & $\begin{array}{l}I E P \\
(\mathrm{pH})\end{array}$ & $\begin{array}{c}C E C \\
(\mathrm{meq} / 100 \mathrm{~g})\end{array}$ \\
\hline Mt* & 58.2 & 19.9 & 5.61 & 0.46 & 0.55 & 2.77 & 0.01 & 2.31 & 0.07 & 10.12 & 55.9 & 3.5 & 98 \\
\hline Mt550 & 59.6 & 19.8 & 4.48 & 0.39 & 0.16 & 3.45 & 0.01 & 1.77 & 0.16 & 10.34 & 0.6 & 8.3 & 97 \\
\hline
\end{tabular}

*Data form Lombardi et al. (2003).

No significant differences were found in the elemental compositions of major components in both samples. Particularly, the constant percentage of aluminium oxide and silica indicated that thermal treatment did not produce mass loss from Mt550 with respect to Mt sample.

Decrease of external SSA value $\left(\mathrm{S}_{\mathrm{N} 2}\right)$ with thermal treatment revealed different textural properties originated in movements of octahedral cations depending on the presence of interlayer cations (Emmerich et al., 1999) or changes in Al coordination, within the octahedral sheet (Torres Sánchez et al., 1999). The IEP $\mathrm{pH}$ value obtained for Mt sample was in agreement with data found for other samples from close sampling areas (Lombardi et al., 2003). The higher IEP pH value obtained for Mt550 sample was assigned to the structural Al leaching with further edges enrichment of the silicate layers, as a consequence of the thermal attack to the surface (Torres Sánchez, 1997), and also its migration to other sites in the octahedral sheet contrarily to $\mathrm{Fe}^{3+}$ behaviour (Heller-Kallai and Rozenson, 1980).

The close CEC values obtained for both samples in agreement with studies performed by Emmerich et al. (1999) indicated that the thermal treatment applied does not affect the CEC values.

Table 2 indicates $\mathrm{HA}$ and $\mathrm{Ca}^{2+}$ adsorption values for all studied samples. As the $\mathrm{pH}$ developed by clay dispersions largely conditioned the HA sorption (Feng et al., 2005), the $\mathrm{pH}$ suspension, for the respective samples, was also indicated. 
The $\mathrm{Mt}_{\mathrm{HA}}$ and $\mathrm{Mt550} \mathrm{HA}$ sample suspensions' $\mathrm{pH}$ values (around $\mathrm{pH} 5.8$ and 8 , respectively) were in the $\mathrm{pH}$ range $(\mathrm{pH}=5-10)$ which corresponded to the range where HA adsorption by Mt was lower (Feng et al., 2005). Tombácz and Szekeres (2004) indicated that HA was bound mostly to the reactive surface sites of clays, Al-OH, prevailing at the edges of clay lamellae, where positive charge could be developed at low pH. In our results, in agreement with Feng et al. (2005) and Majzik and Tombácz (2007a), HA adsorption was higher with lower $\mathrm{pH}$.

Table 2 Adsorbed amounts of $\mathrm{HA}$ and $\mathrm{Ca}^{2+}$ on indicated samples

\begin{tabular}{lccc}
\hline Sample & $p H$ & $H A(\mathrm{mg} / \mathrm{g})$ & $\mathrm{Ca}^{2+}(\mathrm{mg} / \mathrm{g})$ \\
\hline $\mathrm{Mt}_{\mathrm{HA}}$ & 5.7 & 50.0 & - \\
$\mathrm{Mt}_{\mathrm{Ca}}$ & 5.8 & - & 69.6 \\
$\mathrm{Mt}_{\mathrm{CaHA}}$ & 5.7 & 58.5 & 71.7 \\
$\mathrm{Mt550}_{\mathrm{HA}}$ & 8.0 & 27.7 & - \\
$\mathrm{Mt550}$ & 8.1 & - & 35.8 \\
$\mathrm{Mt} 550_{\mathrm{CaHA}}$ & 8.0 & 28.2 & 35.3 \\
\hline
\end{tabular}

Addition of $\mathrm{Ca}^{2+}$ produced a light $\mathrm{HA}$ adsorption increase for the $\mathrm{Mt}$ sample, in agreement with results of Feng et al. (2005), remaining constant for Mt550 sample; while the $\mathrm{Ca}^{2+}$ adsorption was not modified significantly by the presence of $\mathrm{HA}$ on any sample.

The decrease in $\mathrm{HA}$ and $\mathrm{Ca}^{2+}$ adsorption for Mt550 sample (half in quantity with respect to that obtained for the Mt sample) was affected by the suspension $\mathrm{pH}$. To determine whether the interlayer space provides adsorption sites, XRD spectra of all samples were analysed. Figure 1 shows the d 001 reflection peaks of Mt and Mt550 samples, without and with adsorption of $\mathrm{Ca}^{2+}, \mathrm{HA}$ or both.

Adsorption of $\mathrm{HA}$, or $\mathrm{Ca}^{2+}$ alone, in sample $\mathrm{Mt}$, generates an increase of interlayer space from 1.18 to 1.26 and $1.47 \mathrm{~nm}\left(\mathrm{Mt}, \mathrm{Mt}_{\mathrm{HA}}\right.$, and $\mathrm{Mt}_{\mathrm{Ca}}$ samples, respectively), indicating a weak or non-HA entrance (Koyama, 1995), and the formation of classical water bilayer associated with $\mathrm{Ca}^{2+}$ in the $\mathrm{Mt}$ interlayer space (Cases et al., 1997). Meanwhile the d 001 reflection peak found for $\mathrm{Mt}_{\mathrm{CaHA}}$ was close to that of Mt sample, confirming the $\mathrm{HA}-\mathrm{Ca}^{+2}$ complex formations at the edge surfaces (Majzik and Tombácz, 2007a).

The interlayer collapse of Mt550 sample generated a shift of the interlayer space to $0.95 \mathrm{~nm}$ (Ormerod and Newman, 1983). The presence of different adsorbates does not modify the $\mathrm{d} 001$ reflection value found, within the XRD error.

A higher intensity of $\mathrm{d} 001$ reflection peaks was found for samples with humic acid, irrespective of thermal treatment, with respect to samples with $\mathrm{Ca}^{2+}$ and $\mathrm{Ca}-\mathrm{HA}$, which would indicate a higher degree of crystallinity attained by changes in aggregation of the HA-Mt complexes formed (Majzik and Tombácz, 2007a).

Table 3 reports the total SSA values found and the Dapp for all samples.

The decrease of total SSA value $\left(S_{w}\right)$ in all thermal treated samples was mainly originated by the internal SSA (interlayer) decrease discussed in previous paragraphs. A similar water loss values obtained for Mt and Mt550 samples (Table 1) indicated a reversible rehydration of sample Mt550 with time (Emmerich et al., 1999). 
Figure 1 (a) and (b) XRD peaks for d (001) reflection for the indicated samples

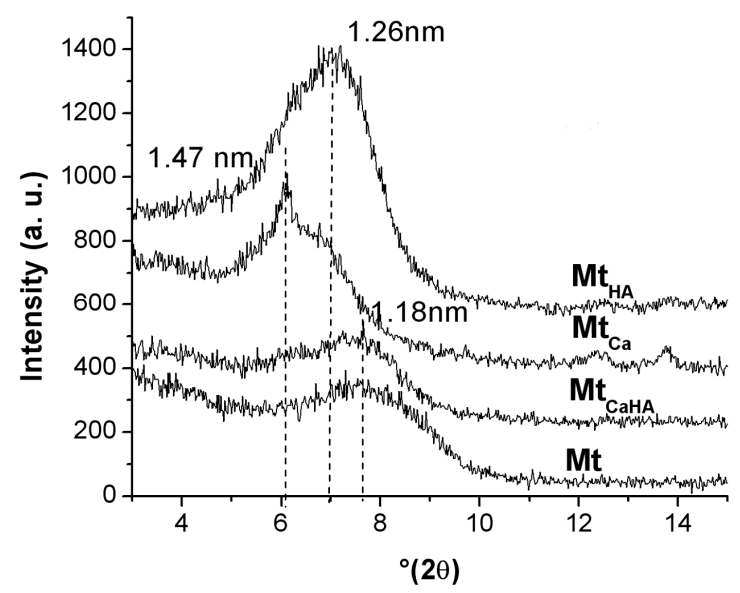

(a)

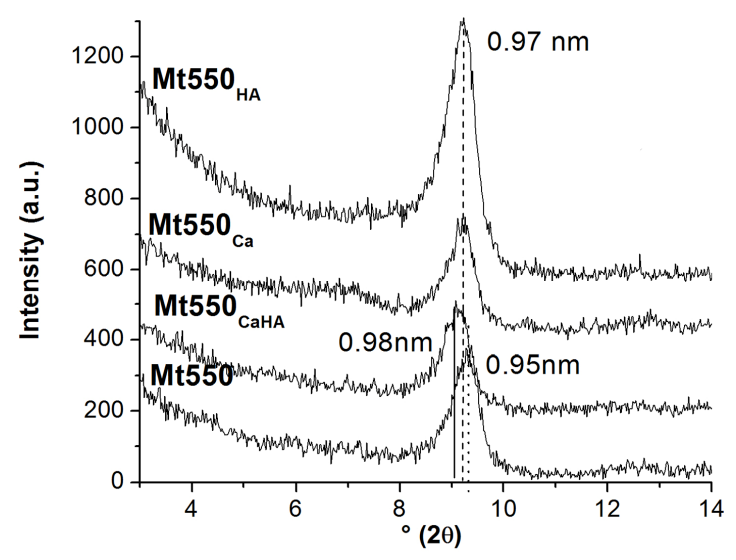

(b)

Table 3 Total SSA and apparent diameter $\left(D_{\text {app }}\right)$ for all samples

\begin{tabular}{lcc}
\hline Sample & ${\text { Total SSA }\left(\mathrm{m}^{2} / \mathrm{g}\right)} D_{\text {app }}(\mathrm{nm})$ \\
\hline $\mathrm{Mt}$ & $670 \pm 10$ & $774 \pm 23$ \\
$\mathrm{Mt}_{\mathrm{HA}}$ & $566 \pm 7$ & $598 \pm 19$ \\
$\mathrm{Mt}_{\mathrm{Ca}}$ & $656 \pm 10$ & $637 \pm 27$ \\
$\mathrm{Mt}_{\mathrm{CaHA}}$ & $572 \pm 7$ & $754 \pm 27$ \\
$\mathrm{Mt550}$ & $140 \pm 2$ & $773 \pm 28$ \\
$\mathrm{Mt550}$ & $90 \pm 1$ & $850 \pm 32$ \\
$\mathrm{Mt} 550_{\mathrm{Ca}}$ & $86 \pm 1$ & $814 \pm 31$ \\
$\mathrm{Mt550}_{\mathrm{CaHA}}$ & $91 \pm 1$ & $778 \pm 26$ \\
\hline
\end{tabular}


The decrease of SSA values in the following order $\mathrm{Mt}_{\mathrm{Ca}} \approx \mathrm{Mt}>\mathrm{Mt}_{\mathrm{HA}}>\mathrm{Mt}_{\mathrm{CaHA}}$ showed no correspondence with the $\mathrm{d} 001$ reflection peak values and consequently with the interlayer capacity of water retention alone. The decrease of total SSA value for $\mathrm{Mt}_{\mathrm{CaHA}}$ with respect to $\mathrm{Mt}_{\mathrm{Ca}}$ sample could be assigned to the calcium ions complexation with $\mathrm{AH}$, where these complexes could cause an increase in the hydrophobicity of the surfaces (Nennemann et al., 2001).

The lower SSA values found for Mt550 with respect to Mt samples point out the collapse of the interlayer space (internal SSA) with thermal treatment (Torres Sánchez et al., 2011), maintaining a similar behaviour to that found for Mt samples. Particularly, the decrease of SSA values with addition of $\mathrm{Ca}^{2+}$ and HA could be explained partly by electrostatic interactions, besides the cation exchange mechanism, as it was indicated for hematite oxide. Vermeer et al. (1998) point out that at high $\mathrm{pH}$, where the surface charge of hematite oxide is negative, and in presence of low salt concentration, the humic acid molecules are adsorbed relatively flat on the oxide surface. The similarity of surface charge developed by Mt550 sample (Table 1, $\mathrm{IEP}_{\mathrm{pH}}=8.3$ ) to those of hematite oxide $\left(\mathrm{IEP}_{\mathrm{pH}}=8.5\right.$, Parks, 1968) would also allow to expect similar association, which in turn generates similar specific surface values among the samples with HA adsorbed.

The addition of $\mathrm{Ca}^{2+}$ or HA produced a decrease in Dapp values for Mt samples. This decrease is reverted in the case of $\mathrm{Mt}_{\mathrm{CaHA}}$, reaching values similar to those found for Mt. For $\mathrm{Mt550}_{\mathrm{Ca}}$ and Mt550 $\mathrm{HA}$ samples, Dapp values were higher than those for Mt550, and this value was also reverted (as in the case of Mt) near to the original value of Mt550 in the case of Mt550 $\mathrm{CaHA}$. Results for Mt were coincident with the study presented by Majzik and Tombácz (2007b), where in the absence of both $\mathrm{HA}$ and $\mathrm{Ca}^{2+}$, clay lamellae are aggregated in edge-to-face form, which can be effectively dispersed by HA addition due to edge coating. In the presence of $\mathrm{Ca}^{2+}$, the $\mathrm{HA}$-coated lamellae are bridged with $\mathrm{Ca}^{2+}$ and higher aggregates can be formed.

In the case of thermal treated samples, the different configuration of $\mathrm{Al}$ in the $\mathrm{Mt}$ structure could originate different interactions, modifying the aggregates formation with respect to Mt samples (Fernández et al., 2013).

The low correlation between Dapp and SSA values would indicate different electrostatic interactions or porosity among the samples studied, which will be estimated.

To evaluate the electrostatic surface interactions among $\mathrm{Mt}$ or Mt550 samples and $\mathrm{HA}$ or $\mathrm{Ca}^{+2}$, measures of $\mathrm{ZP}$ values in a $\mathrm{pH}$ range from 2 to 12 were made (Figure 2).

It must be taken into account that currently available theories for electric double layer cannot be used to accurately interpret ZP of platy particles such as clay minerals. Particularly, cations that compensate the structural charge of smectites are located in the Stern and diffuse layers, originating a constant charge that would not produce electrokinetic phenomena (zeta potential or electrophoretic measurements, Thomas et al., 1999).

However, the measures of $\mathrm{ZP}$ of these minerals as a function of $\mathrm{pH}$ give a negative and constant $\mathrm{ZP}$ value, which is assigned to the relative proportions of basal and edge faces that are exposed to the electrolyte solution, which are both negative for $\mathrm{pH} \geq 3.5$ (Thomas et al., 1999), not allowing the determination of the IEP by microelectrophoresis (Swarten-Allen and Matijevic, 1974). 
Figure 2 Zeta potential curves: (a) raw sample (Mt); (b) thermal treated samples (Mt550). Symbols indicate: $(\boldsymbol{\square})$ clay; $(\bullet) \mathrm{HA} ;(\boldsymbol{\nabla})$ with HA; $(\boldsymbol{\Delta})$ with $\mathrm{Ca}$ and $(\bullet)$ with CaHA samples. Lines are drawn as a guide for the eye (see online version for colours)

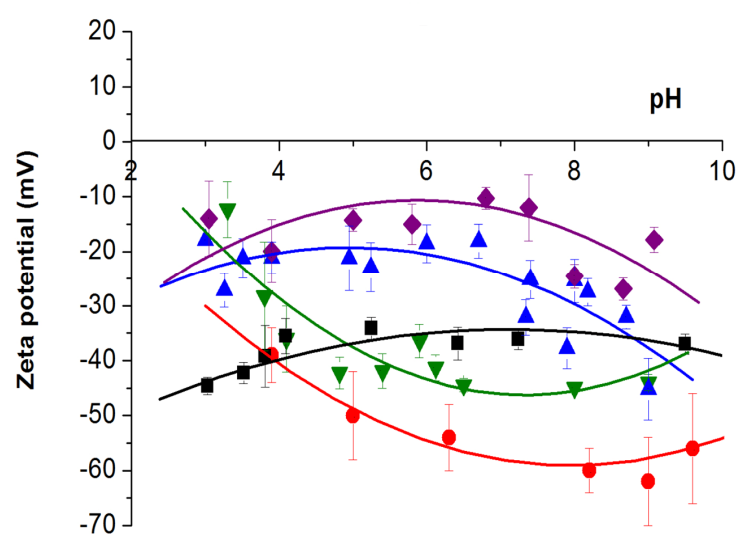

(a)

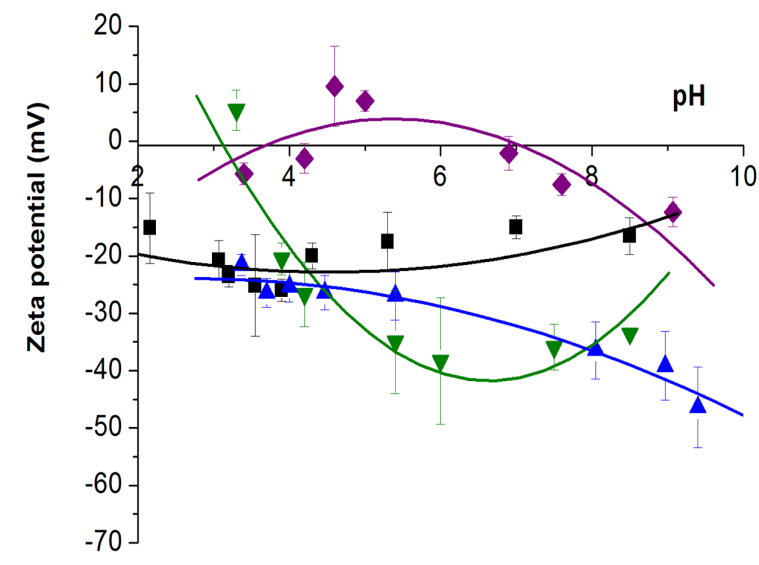

(b)

On the other hand, humic acids possess a range of weak acid groups, including carboxylic and phenolic $\mathrm{OH}$. Most of the chemical groups dissociating, at $\mathrm{pH}<7$, are carboxylic groups (Tipping, 2002). ZP values for HA are negative in the whole $\mathrm{pH}$ range studied (Figure 2). Moreover, these groups have great affinity for $\mathrm{Ca}^{2+}$, and even in the presence of excess of $\mathrm{Ca}^{2+}$ negative values could not be reverted (Majzik and Tombácz, 2007a).

Particularly, in the Mt, the two types of surface charge (negative and permanent in basal faces and variable with the change of $\mathrm{pH}$ in layers edges) determine the value of the $\mathrm{ZP}$. The predominance of negative charges on the basal face compared to the positive charges of particle edges generates a flat $\mathrm{ZP}$ curves between $-30 \mathrm{mV}$ and $-40 \mathrm{mV}$ values in the whole $\mathrm{pH}$ range studied (Sondi et al., 1996; Thomas et al., 1999).

The ZP curves for Mt and HA samples (Figure 2(a)) are in agreement with data found (Durán et al., 2000; Lombardi et al., 2006), attaining up to $-60 \mathrm{mV}$ for HA sample. 
The thermal treatment (Figure 2(b)) generated a decrease in the net negative surface charge of clay (Mt550 with respect to Mt sample), which could be responsible for the formation of larger aggregates and attributed to the release of structural $\mathrm{Al}^{+3}$ cations produced by thermal treatment (Torres Sánchez et al., 2011).

For HA adsorption, $M t_{H A}$ and $\mathrm{Mt550} 0_{\mathrm{HA}}$ samples (at $\mathrm{pH}$ above 5) generated an increase in negative net charge with respect to values obtained for Mt or Mt550 samples, respectively, evidencing the negative surface charge developed by HA functional groups (Tombácz et al.,1984).

The adsorption of $\mathrm{Ca}^{+2}$ in Mt and Mt550 samples produced an opposite $\mathrm{ZP}$ behaviour, when comparison is made to the respective initial samples. A decrease and an increase in the negative net surface charge with respect to Mt and Mt550 samples were found for $\mathrm{Mt}_{\mathrm{Ca}}$ and $\mathrm{Mt550_{ \textrm {Ca } }}$, respectively. However, both $\mathrm{ZP}$ curves (for $\mathrm{Mt}_{\mathrm{Ca}}$ and $\mathrm{Mt550}$ samples) overlapped, within the error range, and were assigned to the $\mathrm{Ca}^{+2}$ exchange produced (Sondi et al., 1996).

The simultaneous presence of $\mathrm{Ca}^{+2}$ and $\mathrm{HA}$ (ternary samples), for both $\mathrm{Mt}_{\mathrm{CaHA}}$ and $\mathrm{Mt550}$ CaHA samples, generated a high decrease of negative net surface charge with respect to Mt and Mt550 samples, which can be assigned to the coordination of $\mathrm{Ca}^{2+}$ by HA ligands (Tipping, 2002). Note that the relative change of the negative net surface charge for both samples is equivalent to $\Delta q_{M t}=q_{\mathrm{Mt}_{\mathrm{CaHA}}}-q_{\mathrm{Mt}} ; \Delta q_{\mathrm{Mt} 550}=q_{\mathrm{Mt550} 0_{\mathrm{CaHA}}}-q_{\mathrm{Mt} 550}$ and $q_{\mathrm{Mt}} \approx q_{\mathrm{Mt} 550}$.

Figure 3 shows an opposite behaviour for pore volume distribution of both samples with $\mathrm{Ca}^{2+}$, $\mathrm{HA}$ or both $\left(\mathrm{Ca}^{2+}\right.$ and $\left.\mathrm{AH}\right)$ adsorption. Cumulative pore size, mean pore diameter (MPD) and maximum pore size values obtained are resumed in Table 4.

The SSA determined by $\mathrm{Hg}$ intrusion was $41 \mathrm{~m}^{2} / \mathrm{g}$ and $4 \mathrm{~m}^{2} / \mathrm{g}$, for Mt and Mt550 samples, respectively. The proximity among the surface values obtained by nitrogen adsorption (Table 1) with those obtained with intrusion of $\mathrm{Hg}$ indicates that there is no substantial volume of pores smaller than those penetrated by $\mathrm{Hg}$ at maximum pressure. The cumulative distribution of pore size (Table 4) with $\mathrm{Ca}^{2+}$ and HA adsorption indicated an increase of pore volume values for $\mathrm{Mt}$ sample series $\left(\mathrm{M}, \mathrm{M}_{\mathrm{HA}}, \mathrm{M}_{\mathrm{CaHA}}\right.$ and $\mathrm{M}_{\mathrm{Ca}}$ ), while the opposite happens (Table 4) for thermal treated sample series (decrease order is: M550, M550 ${ }_{\mathrm{CaHA}}, \mathrm{M}_{550_{\mathrm{HA}}}$ and M550 $\mathrm{Ca}$ ). Lubetkin et al. (1984) analysed the clay surface interactions by means of pressure measurements on clay dispersion. They found that such interactions depend mainly on the nature of the isomorphous substitution in the lattice, where a relation exists between electrical charge and distance of surface separation.

Table 4 Cumulative pore size, mean pore diameter and maximum pore size for all the samples

\begin{tabular}{lccc}
\hline Sample & $\begin{array}{c}\text { Cumulative pore size } \\
\left(\mathrm{mm}^{3} / \mathrm{g}\right)\end{array}$ & Mean pore diameter $(\mu)$ & $\begin{array}{c}\text { Maximum pore } \\
\text { diameter }(\mu)\end{array}$ \\
\hline $\mathrm{Mt}$ & 205 & 0.03 & 5.00 \\
$\mathrm{Mt}_{\mathrm{HA}}$ & 242 & 0.04 & 3.84 \\
$\mathrm{Mt}_{\mathrm{Ca}}$ & 537 & 2.01 & 3.28 \\
$\mathrm{Mt}_{\mathrm{CaHA}}$ & 367 & 0.24 & 4.56 \\
$\mathrm{Mt550}$ & 572 & 2.40 & 4.48 \\
$\mathrm{Mt550}$ & 318 & 0.26 & 4.44 \\
$\mathrm{Mt} 550_{\mathrm{Ca}}$ & 219 & 0.03 & 5.38 \\
$\mathrm{Mt}_{550_{\mathrm{CaHA}}}$ & 520 & 2.22 & 4.48 \\
\hline
\end{tabular}


Figure 3 (a) and (b) Relationship between pores size and volume for the indicated samples

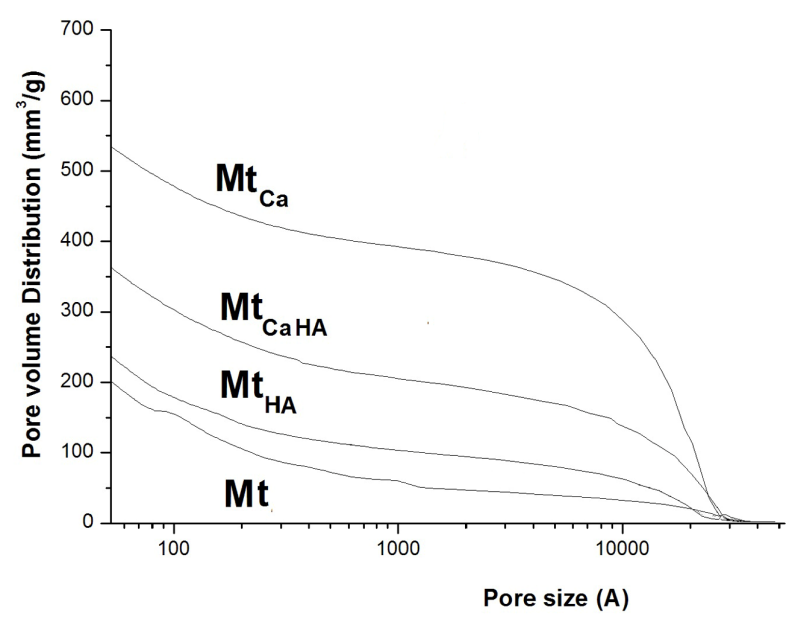

(a)

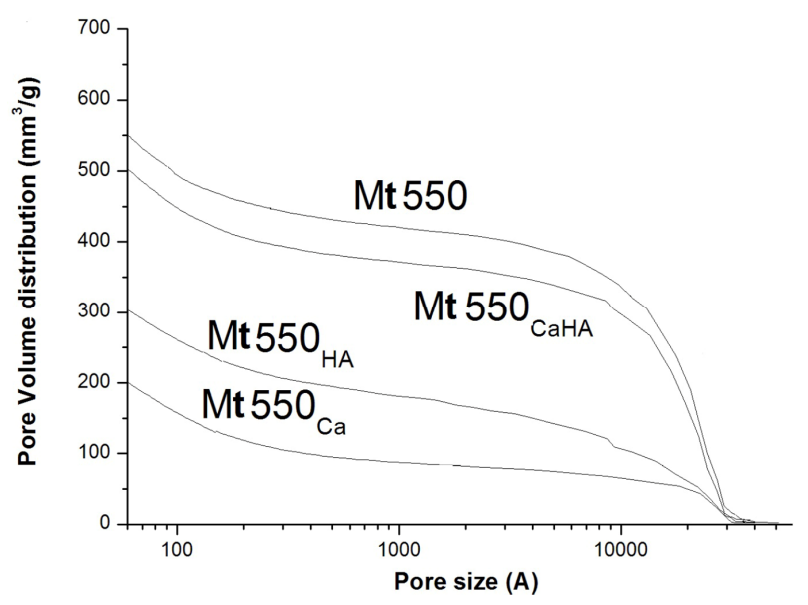

(b)

Maximum pore values, reported in Table 4, were found indistinctly of the thermal treatment, for the samples with $\mathrm{Ca}^{2+}$ adsorbed, showing in the $\mathrm{M} 550_{\mathrm{Ca}}$ sample a bimodal porous profile. The largest relative pore size distribution was found for samples with thermal treatment.

\section{Conclusion}

The modification of $\mathrm{Mt}$ interlayer space ( $\mathrm{d} 001$ reflection peak) indicates the interlayer entrance of $\mathrm{Ca}^{2+}$ which is inhibited in the presence of $\mathrm{HA}$ by complexing $\mathrm{Ca}^{2+}$. Thermal treatment by the collapse of the interlayer can be responsible for the reduction to half the amount of $\mathrm{Ca}^{2+}$ adsorbed, with respect to $\mathrm{Mt}$. 
Water molecule entrance in the interlayer space was modified and inhibited with the presence of $\mathrm{Ca}^{2+}$ and HA molecules, respectively, and so the SSA values were determined. The interlayer space collapse of M550 samples series produced lower SSA values with respect to those of Mt samples series. Negative electric surface charge of Mt and Mt550 samples was increased by $\mathrm{HA}$ and $\mathrm{Ca}^{2}$ adsorption, indicating a main adsorption on the external surface. For ternary systems the coordination of $\mathrm{Ca}^{2+}$ by $\mathrm{HA}$ ligands could produce the decrease of negative electric surface charge with respect to the initial Mt and Mt550 samples.

HA adsorption on Mt samples did not produce changes in the MPD (macropores), while $\mathrm{Ca}^{2+}$ addition increased it even in the presence of HA. The Mt550 sample showed a decrease of the MPD with both $\mathrm{Ca}^{2+}$ and HA adsorption.

\section{Acknowledgements}

The authors acknowledge ANPCyT-FONARSEC (project FS- Nano 008) for financial support. The authors are also thankful to D. Urrejola and M. Olivelli for technical assistance and to Consejo Nacional de Investigaciones Científicas y Técnicas de la República Argentina (CONICET).

\section{References}

Amezkieta, E. (1999) 'Soil aggregate stability: a review', Journal of Sustainable Agriculture, Vol. 14, pp.83-151.

An, J., Jho, E.H. and Nam, K. (2015) 'Effect of dissolved humic acid on the Pb bioavailability in soilsolution and its consequence on ecological risk', Journal of Hazardous Materials, Vol. 286, pp.236-241.

Arnarson, T.S. and Keil, R.G. (2000) 'Mechanisms of pore water organic matter adsorption to montmorillonite', Marine Chemistry, Vol. 71, pp.309-320.

Barancikova, G., Senesi, N. and Brunetti, G. (1997) 'Chemical and spectroscopic characterization of humic acids isolated from different Slovak soil types', Geoderma, Vol. 78, pp.251-266.

Bittner, M., Janosek, J., Hilscherova, K., Giesy, J., Holoubek, I. and Blaha, L. (2006) 'Activation of ah receptor by pure humic acids', Environmental Toxicology, Vol. 21, pp.338-342.

Bojemueller, E., Nennemann, A. and Lagaly, G. (2001) 'Enhanced pesticide adsorption by thermally modified bentonites', Applied Clay Science, Vol. 18, pp.277-284.

Cases, J.M., Berend, I., Francois, M., Uriot, J-P., Michot, L.J. and Thomas, F. (1997) 'Mechanism of adsorption of water vapor by homoionic montmorillonite. 3. The $\mathrm{Mg} 2+, \mathrm{Ca} 2+, \mathrm{Sr} 2+$ and Ba2+ exchanged forms', Clays and Clay Minerals, Vol. 45, pp.8-22.

Czímerová, A., Bujdákand, J. and Dohrmann, R. (2006) 'Traditional and novel methods for estimating the layer charge of smectites', Applied Clay Science, Vol. 34, Nos. 1-4, pp.2-13.

Durán, J.D.G., Ramos-Tejada, M.M., Arroyo, F.J. and González-Caballero, F. (2000) 'Rheological and electrokinetic properties of Na-montmorillonite suspensions', Journal Colloids and Interface Science, Vol. 229, pp.107-117.

Emmerich, K., Madsen, F. and Kahr, G. (1999) 'Dehydroxylation behaviour of heat treated and steam treated homoionic cis-vacant montmorillonites', Clays and Clay Minerals, Vol. 47, pp.591-604.

Feng, X., Simpson, A.J. and Simpson, M. (2005) 'Chemical and mineralogical controls on humic acid sorption to clay mineral surfaces', Journal Organic Geochemistry, Vol. 36, No. 11, pp.1553-1566. 
Fernández, M., Alba, M.D. and Torres Sánchez, R.M. (2013) 'Effects of thermal and mechanical treatments on montmorillonite homoionized with mono- and polyvalent cations: Insight into the surface and structural changes', Colloids and Surfaces A: Physicochem. Eng. Aspects, Vol. 423, pp.1-10.

Heller-Kallai, L. and Rozenson, P. (1980) 'Dehydroxylation of dioctahedral phyllosilicates', Clays and Clay Minerals, Vol. 28, pp.355-368.

Hseu, Y.C., Chen, S.C., Chen, Y.L., Chen, J.Y., Lee, M.L., Lu, F.J., Wu, F.Y., Lai, J.S. and Yang, H.L. (2008) 'Humic acid induced genotoxicity in human peripheral blood lymphocytes using comet and sister chromatid exchange assay', Journal of Hazardous Materials, Vol. 153, pp.784-791.

Hur, J., Lee, B.M. and Shin, H.S. (2011) 'Microbial degradation of dissolved organic matter (DOM) and its influence on phenanthrene-DOM interactions', Chemosphere, Vol. 85, pp.1360-1367.

Kappler, A., Benz, M., Schink, B. and Brune, A. (2004) 'Electron shuttling via humic acids in microbial iron(III) reduction in a freshwater sediment', FEMS Microbiology Ecology, Vol. 47, pp.85-92.

Kar, S., Maity, J.P., Jean, J-S., Liu, C-C., Bibhashnath, C., Lee, Y-C., Bundschuh, J., Chen, C-Y. and Li, Z. (2011) 'Role of organic matter and humic substances in the binding and mobility of arsenic in a Gangetic aquifer', Journal of Environmental Science and Health, Part A, Vol. 46, pp.1231-1238.

Kihara, Y.Y., Tanaka, M., Gumiri, S.A., Hosokawa, T., Tanaka, S., Saito, T. and Kurasaki, M. (2014) 'Mechanism of the toxicity induced by natural humic acid on human vascular endothelial cells', Environmental Toxicology, Vol. 29, No. 8, pp.916-925.

Koyama, M. (1995) 'Adsorption of humic acid on Ca-montmorillonite', Soil Science and Plant Nutrition, Vol. 41, No. 2, pp.215-223.

Liang, H-J., Tsai, Ch-L., Chen, P-Q. and Lu, F-J. (1999) 'Oxidative injury induced by synthetic hum1c acid polymer and monomer in cultured rabbit articular chondrocytes', Life Sciences, Vol. 65, No. 11, pp.1163-1173.

Liu, A. and Gonzalez R.D. (1999) 'Adsorption/desorption in a system consisting of humic acid, heavy metals, and clay minerals', Journal of Colloid and Interface Science, Vol. 218, pp. $225-232$.

Lombardi, B., Baschini, M. and Torres Sánchez, R.M. (2003) 'Bentonite deposits of Northern Patagonia', Applied Clay Science, Vol. 22, pp.309-312.

Lombardi, B., Torres Sánchez, R.M., Eloy, P. and Genet, M. (2006) 'Interaction of thiabendazole and benzimidazole with montmorillonite', Applied Clay Science, Vol. 33, pp.59-65.

Lubetkin, S., Middleton, S. and Ottewil, R. (1984) 'Some properties of clay water dispersions', Philosophical Transactions of the Royal Society A., Vol. 311, pp.353-368.

Majzik, A. and Tombácz, E. (2007a) 'Interaction between humic acid and montmorillonite in the presence of calcium ions, I. Interfacial and aqueous phase equilibria: adsorption and complexation', Organic Geochemistry, Vol. 38, pp.1319-1329.

Majzik, A. and Tombácz, E. (2007b) 'Interaction between humic acid and montmorillonite in the presence of calcium ions, II. Colloidal interactions: Charge state, dispersing and/or aggregation of particles in suspension', Organic Geochemistry, Vol. 38, pp.1330-1340.

Michot, L.J. and Villieras F. (2006) 'Developments in Clay Sci. Surface area and porosity', in Bergaya, F., Theng, B.K. and Lagaly, G. (Eds.): Handbook of Clay Science, Elsevier, Amsterdam, pp.965-978.

Nelson, P.N., Baldock, J.A., Clarke, P., Oades, J.M. and Churchman, G.J. (1999) 'Dispersed clay and organic matter in soil: their nature and associations', Australian Journal of Soil Research, Vol. 37, pp.289-315.

Nennemann, A., Kulbach, S. and Lagaly, G. (2001) 'Entrapping pesticides by coagulating smectites', Applied Clay Science, Vol. 18, pp.285-298. 
Ormerod, E.C. and Newman, A.C.D. (1983) 'Water sorption on Ca-saturated clays: 2. Internal and external surfaces of montmorillonite', Clay Minerals, Vol. 18, pp.289-299.

Park, S.I., Kwak, I.S., Bae, M.A., Mao, J., Won, S.W. and Han, D.H. (2012) 'Recovery of gold as a type of porous fiber by using biosorption followed by incineration', Bioresources Technology, Vol. 104, pp.208-214.

Parks, G.A. (1968) 'The isoelectric point of solid oxides, solid hydroxides and aqueous hydroxo complex systems', Chemical Reviews, Vol. 65, pp.177-198.

Sondi, I., Biscan, J. and Pravdic, V. (1996) 'Electrokinetics of pure clay minerals revisited', Journal of Colloids and Interface Science, Vol. 178, pp.514-522.

Stevenson, F.J. (1982) Humus Chemistry, Genesis, composition, Reaction, J. Wiley and Sons, New York, p.443.

Swarten-Allen, L.S. and Matijevic, E. (1974) 'Surface and colloid chemistry of clays', Chemical Reviews, Vol. 74, pp.385-400.

Thomas, F., Michot, L.J., Vantelon, D., Montarges, E., Prelot, B., Cruchaudet, M.J. and Delon, F. (1999) 'Layer charge and electrophoretic mobility of smectites', Colloids and Surfaces. A, Vol. 159, pp.351-358.

Tiller, K.G. and Smith, L.H. (1990) 'Limitations of EGME retention to estimate the surface area of soils', Australian Journal of Soil Research, Vol. 28, pp.1-26.

Ting, H.C., Yen, C.C., Chen, W.K., Chang, W.H., Chou, M.C. and Lu, F.J. (2010) 'Humic acid enhances the cytotoxic effects of arsenic trioxide on human cervical cancer cells', Environ. Toxicol. Pharmacol., Vol. 29, pp.117-125.

Tipping, E. (2002) Cation Binding by Humic Substances, Cambridge University Press, Cambridge.

Tombácz, E. and Szekeres, M. (2004) 'Colloidal behaviour of aqueous montmorillonite suspensions: the specific role of $\mathrm{pH}$ in the presence of indifferent electrolytes', Applied Clay Science, Vol. 27, pp.75-94.

Tombácz, E., Gilde, M. and Szántó, F. (1984) 'The effects of Na- salicylate and Na-fulvate on the stability and rheological properties of Na-montmorillonite suspensions', Acta Physica et Chemica, Vol. 30, pp.165-174.

Torres Sánchez, R.M. (1997) 'Mechanochemical effects on physicochemical parameters of homoionic smectite', Colloids and Surface A, Vol. 127, pp.135-140.

Torres Sánchez, R.M. and Falasca, S. (1997) 'Specific surface area and surface charges of some argentinean soils', Zeitschrift für Pflanzenernährung und Bodenkunde, Vol. 160, pp.223-226.

Torres Sánchez, R.M., Basaldella, E. and Marco, J.F. (1999) 'The effect of thermal and mechanical treatments on kaolinite characterization by XPS and IEP measurements', Journal Colloids and Interface Science, Vol. 215, pp.339-344.

Torres Sánchez, R.M., Genet, M.J., Gaigneaux, E.M., dos Santos Afonso, M. and Yunes, S. (2011) 'Benzimidazole adsorption on the external and interlayer surfaces of raw and treated montmorillonite', Applied Clay Science, Vol. 53, pp.366-373.

Tschapek, M., Torres Sánchez, R.M. and Wasowski, C. (1989) 'Handy methods for determining the isoelectric point of soils', Zeitschrift für Pflanzenernährung und Bodenkunde, Vol. 152, pp.73-76.

Vacca, W.D.J., Bleam, F. and Hickey, W.J. (2005) 'Isolation of soil bacteria adapted to degrade humic acid-sorbed phenanthrene', Applied Environmental Microbiology, Vol. 71, No. 7, pp.3797-3805.

Vermeer, A., van Riemsdijk, W. and Koopal, L. (1998) 'Adsorption of humic acid to mineral particles 1. Specific and electrostatic interactions', Langmuir, Vol. 14, pp.2810-2819.

Wang, M., Bai, Y., Chen, W., Markert, B., Peng, C. and Ouyang, Z. (2012) 'A GIS technology based potential eco-risk assessment of metals in urban soils in Beijing, China', Environmental Pollution, Vol. 161, pp.235-242. 
Wu, P., Zhang, Q., Dai, Y., Zhu, N., Dang, Z., Li, P., Wu, J. and Wang, X. (2011) 'Adsorption of $\mathrm{Cu}(\mathrm{II}), \mathrm{Cd}(\mathrm{II})$ and $\mathrm{Cr}(\mathrm{III})$ ions from aqueous solutions on humic acid modified Ca-montmorillonite', Geoderma, Vol. 164, Nos. 3-4, pp.215-219.

Yang, H.L., Hseu, Y.C., Hseu, Y.T., Lu, F.J., Liu, E. and Lai, J.S. (2004) 'Humic acid induceds apoptosis in human premyelocytic leukemia HL-60 cells', Life Science, Vol. 75, pp.1817-1831.

Young, D. and Smith, D.E. (2000) 'Simulations of clay mineral swelling and hydration: dependence upon interlayer ion size and charge', Journal Physical Chemistry B, Vol. 104, pp.9163-9170. 